THOMAS HILL GREEN

Tekst został przetłumaczony na postawie: T. H. Green, Legislative Interference in Moral Matters, w: tenże, Collected Works of T. H. Green. Volume V. Additional Writings, ed. P. P. Nicholson, Continuum Publishing Co., 1997, s. 31-34. Serdecznie dziękujemy wydawnictwu Continuum Publishing Co. za zgodę na publikację tłumaczenia.

\title{
Ustawodawcza ingerencja w kwestie moralne
}

7 agadnienie to doczekało się już wielu błędnych przedstawień powodoLanych głównie niestosownymi analogiami czynionymi między grecką тó $\lambda_{1 \varsigma}$ [polis, miasto] i współczesnym państwem. My będziemy mówić [tu] o narodzie jako zjednoczonej całości, przesiąkniętej duchem „jednym i niepodzielnym", której kierowniczym sumieniem (conscience) jest rząd, zaś najwyższym wyrazem ustawodawstwo. Sformułowania takie zapożyczamy

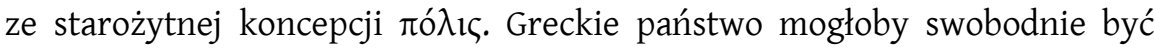
określonym mianem zintensyfikowanej i powiększonej jednostki. Jego członkowie, żyjąc w zasadzie [jedynie] w ramach wąsko zakrojonych granic miejskich murów, w większości przypadków osobiście się znali; wyrósłszy ze wspólnych przodków, o których bezustannie im przypominano, ze wspólną religią polityczną (political-religion) i wspólną własnością państwową (state-property) [przeznaczoną im] do obrony, będąc jednocześnie pozbawionymi religii duchowej (spiritual religion), która uczyniłaby ich życiowe cele tak różnymi, nie mieli żadnych zasadniczo antagonistycznych interesów. Spory, które między nimi wybuchały, zdawały się mieć swe źródło w różnorodności umiejętności jednego i tego samego umysłu pracujących na rzecz i jednocześnie przeciwdziałających temu samemu celowi. Rząd mógł kierować różnymi członkami społeczności, podobnie jak sumienie lub miłość własna kieruje wykorzystaniem niektórych afektów dla dobra człowieka jako całości. Tak więc, czymkolwiek by nasz ideał ostatecznej doskonałości społe-

* Pełen tekst tłumaczenia dostępny jest w drukowanej wersji pisma. 
czeństwa nie był, musimy przyznać, że taki język nie znajduje zastosowania w przypadku państwa współczesnego. (...)

P R Z E Ł O Ż Y Ł J A N U S Z G R Y G I E Ń Ć 
JANUSZ GRYGIEŃĆ

Instytut Politologii UMK

\section{Funkcje instytucji państwowych w projekcie moralnego doskonalenia ludzkości w filozofii T. H. Greena a ideologia Nowego Liberalizmu}

$\mathbf{M}$

iejsce Thomasa H. Greena w filozofii politycznej brytyjskiego liberalizmu nie jest do końca określonym i w dalszym ciągu pozostaje przedmiotem sporów badaczy. Faktem jest, że lata jego największego intelektualnego oddziaływania zbiegają się ze zmianami ideologicznymi, które pod koniec XIX wieku przechodziła brytyjska Partia Liberalna. Część badaczy, biorąc pod uwagę fakt, że idealizm à la Green przez dziesięciolecia stanowił dominujący nurt intelektualny na uniwersytetach Anglii i Szkocji, wysuwa wniosek, iż odejście od ideologii tzw. manchesterskiej szkoły liberalizmu na rzecz tzw. Nowego Liberalizmu można przypisać głównie właśnie działalności Greena ${ }^{1}$. Nie tylko zdroworozsądkowy sceptycyzm nakazuje uznawać tezę, że to właśnie Green był, jeśli nie inspiratorem, to przynajmniej katalizatorem zmian, które ostatecznie zaowocowały ideą welfare state, za mocno przesadzoną. Argumentem przeciw niej jest też fakt, że choć autor ten otwarcie polemizował ze wszystkimi przedstawicielami utylitaryzmu, nie czyniąc zbyt dużego rozróżnienia między Helwecjuszem, Benthamem i J. S. Millem (do tradycji tej zaliczał także Hume'a), to jednak ,uspołecznienie" zarówno radykalizmu filozoficznego, jak i samego liberalizmu przypisywane jest, jak powszechnie wiadomo, właśnie Millowi. Różnice między nim a Greenem, choć nie do pogodzenia w kwestiach epistemologicznych, metafizycznych, a w znacznej mierze także etycznych, w kwestiach politycznych

M. Richter, The Politics of Conscience: T. H. Green and His Age, Cambridge 1964, s. 267-291, D. Nicholls, Positive Liberty 1880-1914, „American Political Science Review”, vol. 56, no. 1, 1962; samo ustosunkowanie Greena do kwestii społecznej jest o tyle interesujące, że zawsze za głównego swego „idola” uznawał Johna Brighta - jednego z najbardziej zdeklarowanych zwolenników „manchesteryzmu” - czego dowodów można doszukiwać się w ostatnich zdaniach powyższego, wczesnego eseju Greena, który jednak w późniejszych swych pracach za tak oczywistą już uznawał potrzebę ingerencji państwa w życie jednostek dla umożliwienia im i ich najbliższym pełniejszego samo-rozwoju. 
zdają się być ograniczonymi². Podobny nacisk na samodoskonalenie jednostek i mającą być jego gwarantem niezbędność interwencji instytucji państwowych w życie obywateli, wyraźna skłonność do uznania potrzeby realizacji tego rodzaju wolności, którą za I. Berlinem określamy dziś „pozytywną", stawiają pod znakiem zapytania rzeczywistą „przełomowość” myśli brytyjskiego idealizmu w tej kwestii ${ }^{3}$.

Przeciwnicy tego stanowiska jednak także dysponują przekonującymi argumentami. Twierdzą, że choć może rzeczywiście ideologicznie wpływ myśli Greena nie był tak doniosły jak niektórzy utrzymują, to niewątpliwie jako największy żyjący filozof Oxfordu wywarł on trudny do przecenienia wpływ na całe pokolenie brytyjskich ideologów, polityków i liberalnych reformatorów społecznych, którzy otwarcie do inspiracji idealistycznych się przyznawali. Wśród nich mamy duchownych anglikańskich - Henry'ego Scotta Hollanda i Charlesa Gore'a, którzy obrali sobie za cel „przełożenie” filozoficznych tez Greena na język teologii chrześcijańskiej ${ }^{4}$ (co zaowocowało m.in. publikacją w 1889 roku zbioru esejów pod tytułem „Lux Mundi” skutkującą podejrzeniami o apostazję obu autorów) oraz praktyki społecznej (założenie Christian Social Union jako platformy realizacji „socjalnego powołania" chrześcijan), działaczy Charity Organization Society - Bernarda i Helen Bosanquet, Sidney'a i Beatrice Ball - socjalistycznych członków Fabian Society, ale także właśnie ideologów i popularyzatorów idei Nowego Libera-

2 Por. H. Halloway, Mill and Green on the Modern Welfare State, „Western Political Quarterly”, vol. 13, no. 2, 1960, J. H. Randall Jr., T. H. Green: the Development of English Thought from J. S. Mill to F. H. Bradley, ,Journal of the History of Ideas”, vol. 27, 1966, I. M. Greengarten, Thomas Hill Green and the Development of Liberal-Democratic Thought, London Toronto Buffalo 1981.

3 Taką opinię wyraził M. Freeden w swym dziele poświęconym intelektualnym korzeniom Nowego Liberalizmu (M. Freeden, The New Liberalizm. An Ideology of Social Reform, Oxford 1978, s. 55-59); autor ten upatrywał także źródeł społecznie zorientowanego liberalizmu w tradycji pozytywistycznej, utylitarnej i ewolucjonistycznej; jak wiadomo, Green otwarcie polemizował z Darwinem, gdyż uważał teorię ewolucji za niezgodną z chrześcijańskim objawieniem, co więcej - za skutkującą z konieczności negacją jakiejkolwiek formy idealizmu i transcendentnych form religijności; co najmniej zastanawiający jest jednak fakt, że Freeden D.G. Ritchie'ego (który w swej filozofii łączył heglizm z darwinizmem i który był jednym z uczniów Greena) gotów jest z taką łatwością z greenowskiego „dziedzictwa” intelektualnego wyłączyć (por. M. Carter, T. H. Green and the Development of Ethical Socialism, Charlottesville 2003, s. 136-144).

4 Jako przykład może służyć utożsamienie przez Hollanda wolności negatywnej z samolubnością i grzesznością, zaś pozytywnej z Boskim rozumem i objawieniem (zob. M. Carter, dz. cyt., s. 111); ciekawym jest fakt, że w swych dziełach Green zmierzał do czegoś, w pewnym sensie, zupełnie przeciwstawnego, a mianowicie przełożenia języka teologii na język filozofii (zob. J. Grygieńć, Greenowska krytyka teologii chrześcijańskiej, „Dialogi polityczne”, nr 8, 2007, s. 143-153). 
lizmu - Leonarda Trelawny'a Hobhouse'a i Johna Atkinsona Hobsona ${ }^{5}$. Obaj na greenowski sposób łączyli nacisk na samorealizację jednostek obecny już u Milla z kantowskim racjonalizmem ${ }^{6}$. Niektórzy twierdzą też, że niezależnie od tego, czy Greena można określić wręcz mianem „ojca” Nowego Liberalizmu, niewątpliwym jest, że wpływ jaki miał na założycieli i późniejszych członków takich organizacji i przedsięwzięć jak np. University Settlement Movement, Workers' Educational Association ${ }^{7}$, nie mógł pozostać bez znaczącego wpływu na charakter i specyficznego „ducha” brytyjskich reformatorów politycznych i społecznych końca XIX i początku XX wieku, a poprzez nich - na redefinicję podstawowych założeń Partii Liberalnej.

J A N U S Z G R Y G I E Ń Ć

Obaj niechętnie przy tym odnosili się do heglowskiej dialektyki; w przypadku Hobsona występują jeszcze dodatkowe rozbieżności z filozofią Greena - jedną z takich płaszczyzn stanowi problematyka zakresu wolności nabywania, gdyż Hobson przeciwny był stanowczo dopuszczeniu wolnej gry sił rynkowych; niekiedy wskazuje się także, że nie jest do końca oczywistym stosunek Hobhouse'a do tradycji brytyjskiego idealizmu, a to z powodu jego bezpardonowego ataku na filozofię polityczną Bernarda Bosanqueta (wyłożoną przez tego ostatniego $\mathrm{w}$ głośnej Philosophical Theory of the State) przeprowadzonego $\mathrm{w}$ jego dziele Metaphysical Theory of the State; tym, co budzi wątpliwości niektórych komentatorów (zob. m.in. P. P. Nicholson, Political Philosophy of British Idealists. Selected Studies, Cambridge 1990, s. 189-190) jest fakt, że Bosanquet, w stanowiącej główny przedmiot krytyki, swojej teorii woli powszechnej, nie odchodzi tak daleko od filozofii Greena i Bradleya, jak uważa Hobhouse; stawia to pod znakiem zapytania możliwość spójnej afirmacji filozofii Greena przy jednoczesnym odrzuceniu podstaw filozofii Bosanqueta.

Zob. D. Weinstein, The New Liberalizm of L. T. Hobhouse and the Reenvisioning of NineteenthCentury Utilitarianism, w: "Journal of the History of Ideas”, vol. 57, no. 3, 1996, s. 487-507; J. W. Seaman, L. T. Hobhouse ant the Theory of "Social Liberalism”, w: „Canadian Journal of Political Science/Revue canadienne de science politique”, vol. 11, no. 4, 1978, s. 777-801; M. Freeden, J. A. Hobson as a New Liberal Theorist: Some Aspects of his Social Thought Until 1914, w: "Journal of the History of Ideas”, vol. 34, no. 3, 1973, s. 421-443.

Por. D. P. Leighton, The Greenian Moment. T.H. Green, Religion and Political Argument in Victorian Britain, Charlottesville 2004, s. 279-313. 